E3S Web of Conferences 1, 16006 (2013)

DOI: $10.1051 / \mathrm{e} 3$ sconf/20130116006

(c) Owned by the authors, published by EDP Sciences, 2013

\title{
Potentially toxic elements content in the surficial marine sediment (peloid) from Makirina bay (central Adriatic)
}

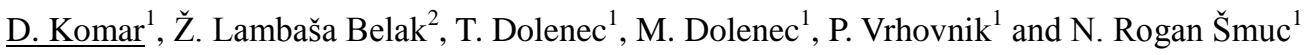 \\ ${ }^{1}$ Faculty of Natural Sciences and Engineering, Department of Geology, University of Ljubljana, Aškerčeva 12,1000 \\ Ljubljana, Slovenia, darja.komar@ntf.uni-lj.si \\ 2 Šibenik-Knin County, 22000 Šibenik, Croatia
}

\begin{abstract}
The aim of the present study was to determine the concentrations of several potentially toxic elements (PTE) in the recent marine sediment of Makirina bay (central Adriatic), which could according to its organoleptic properties be used as a virgin material for medical treatment, wellness and relax purposes. Sediment samples were collected in June and July 2010 from six different sites in the central part of the bay. The range of measured elemental concentrations in analysed surficial sediment were: As (11-15,8 ppm), $\mathrm{Cr}$ (61,6 -109,5 ppm), Cu (19,4-54,2 ppm), Pb (16,8-29,6 ppm) and Zn (37-52 ppm). Sediment PTE pollution assessment was performed using contamination factor $(\mathrm{CF})$, contamination degree $\left(\mathrm{C}_{\mathrm{deg}}\right)$ and pollution load index (PLI). The calculated environmental index values show a low to moderate contamination status of sediment. Future geochemical investigation on these sediments are necessary prior actual use in various therapeutic treatment.
\end{abstract}

Keywords: Makirina bay, marine sediments, peloids, potentially toxic elements (PTE), contamination factor $(\mathrm{CF})$, contamination degree $\left(\mathrm{C}_{\mathrm{deg}}\right)$, pollution load index (PLI)

\section{Introduction}

Peloids are fine-grained sediments, produced by different geological and biological processes. Because of their positive and beneficial effect on human organisms their mixture with water could often be used for mud baths and cataplasms (Novak, 1963). In modern medicine peloids are still very useful for treatment of various diseases. They are used for recovering muscle-bone-skin pathologies; applications of thermal muds are also employed for wellness and relax purposes (Veniale et al., 2007).

To be suitable for balneotherapy, certain qualities of peloids are necessary; one of them is chemical composition of peloids. Special attention should be given to potentially toxic elements ( $\mathrm{As}, \mathrm{Cd}, \mathrm{Cr}, \mathrm{Cu}, \mathrm{Hg}, \mathrm{Ni}, \mathrm{Pb}$, $\mathrm{Zn}, \ldots)$. The abundance of potentially toxic elements (PTE) in peloids must be very carefully controled because of their potential hazardous effects on health (Summa et al., 1998, Mascolo et al., 1999, Vreča et al., 2000, Mascolo et al., 2004, Veniale et al. 2004, Vreča and Dolenec, 2005, Tateo and Summa, 2007, Gomes and Silva, 2007, Veniale et al., 2007, Miko et al., 2007, Miko et al., 2008, Tateo et al., 2009, Karakaya et al., 2010, Carretero et al., 2010, Mihelčić et al., 2011, Rebelo et al., 2011).
Along the eastern Adriatic coast several deposits of fine-grained sediments can be found. One of the most important accumulations of sediments is Makirina bay, located near Šibenik city. Marine sediment of Makirina bay could according to its organoleptic properties be treated as peloid material and therefore it could be used as virgin material for different therapeutic purposes.

The main objectives of the present study was (1) to determine the level of several PTE (As, $\mathrm{Cr}, \mathrm{Cu}, \mathrm{Pb}$ and $\mathrm{Zn}$ ) in the sediments from Makirina bay, (2) to compare the PTE contents between Makirina bay sediment, the surficial sediment of central Adriatic (Dolenec et al., 1998) and the »virgin « clay, the basic ingredient used for the preparation of the peloid muds in spa centers in northern Italy (Veniale et al., 2004) and (3) to employ different types of environmental indices to assess the PTE contamination of Makirina marine sediment.

\section{Materials and Methods}

Makirina bay represents the southern part of the Pirovac bay and it is located in the central Dalmatia (Croatia), 18 $\mathrm{km} \mathrm{NW}$ of Šibenik city. The surroundings of the bay is cultivated (olives and vineyards) and sparsely populated. The only larger settlement near Makirina bay is Pirovac with approximately 2000 inhabitants. The climate in the 
region is typical Mediterranean. The wider area of Makirina is built mostly of early and late cretaceous carbonate rocks and quaternary sediments. Along the SW coast of the bay is the main road which connects mainland and the Murter island. Makirina bay is smaller bay (approximately $1250 \mathrm{~m}$ in lenght and $300 \mathrm{~m}$ in width) with a N-S extension. The deepth of the sea in the southern part of the bay rarely exceeds $0,5 \mathrm{~m}$ and increases towards the NE part of the bay (seaward direction) to a deepth of $4,5 \mathrm{~m}$. The bottom of the bay is covered by $0-3 \mathrm{~m}$ thick sediment, mostly covered by sea grass and benthic algae. Sediment body of Makirina bay consist of approximately $410.000 \mathrm{~m}^{3}$ of peloid (Šparica et al., 1989).

Sediment core samples were taken in June and July 2010 from 6 different sites in the central part of the bay. Samples were collected with hand-driven Plexiglas core samplers (40 cm long and $3,5 \mathrm{~cm}$ inner diameter). Samples were immediately frozen and kept as such until further analysis. In the laboratory cores were divided into $5 \mathrm{~cm}$ long sections and air-dried. Non-representative debris (large rocks and organic debris) were removed with sieving. Samples were homogenized to a fine powder $(<63 \mu \mathrm{m})$ in an agate mortar.

Sediment samples were analysed for PTE content in a certified commercial Canadian laboratory (Acme Analytical Laboratories Ltd.). Samples were leached in hot $\left(95^{\circ} \mathrm{C}\right)$ Aqua Regia and analysed by ICP-MS. The analytical precision and accuracy were better than $\pm 5 \%$ for the analysed elements ( $\mathrm{As}, \mathrm{Cr}, \mathrm{Cu}, \mathrm{Pb}$ and $\mathrm{Zn}$ ). This was indicated by the results of the duplicate measurements in 10 sediment samples as well as duplicate measurements of the G-1 and SO-1 standards.

For analysed PTE different environmental indices (contamination factor, contamination degree and pollution load index) were calculated. Contamination factor $(\mathrm{CF})$ and contamination degree $\left(\mathrm{C}_{\mathrm{deg}}\right)$ were proposed by Hakanson (1980) in order to describe the contamination of a given toxic substance in an investigated area. $\mathrm{CF}$ is expressed as: $\mathrm{CF}=\mathrm{C}_{\mathrm{s}} / \mathrm{C}_{\mathrm{b}}$, where $\mathrm{C}_{\mathrm{s}}$ is the mean content of substance in the sample and $\mathrm{C}_{\mathrm{b}}$ is the background value for the substance. Hakanson (1980) classified CF into four categories: CF $<1$ (low contamination), $\quad 1<\mathrm{CF}<3 \quad$ (moderate contamination), $3<\mathrm{CF}<6$ (considerable contamination) and $\mathrm{CF}>6$ (very high contamination). $\mathrm{C}_{\mathrm{deg}}$ is defined as the sum of contamination factors for all elements examined. $\mathrm{C}_{\mathrm{deg}}$ is also divided into four classes: $\mathrm{C}_{\mathrm{deg}}<8$ (low degree of contamination), $\quad 8<\mathrm{C}_{\mathrm{deg}}<16 \quad$ (moderate degree of contamination), $16<\mathrm{C}_{\mathrm{deg}}<32$ (considerable degree of contamination) and $\mathrm{C}_{\mathrm{deg}}>32$ (very high degree of contamination). The pollution load index (Tomlinson et. al, 1980) provides a simple, comparative means for assessing the level of metal pollution of the sediment; the pollution load index (PLI) was calculated using the equation:

$$
\mathrm{PLI}=\sqrt[n]{(C F 1 \cdot C F 2 \cdot C P 3 * \ldots \cdot C F n j}
$$

If $\mathrm{PLI}>1$ it means that pollution exist otherwise (if $\mathrm{PLI}<1$ ) there is no metal pollution in the sediment.

\section{Results and Discussion}

The concentrations of PTE in the surficial sediment from Makirina bay and their minimum, maximum and mean values are present in Table 1.

Tab. 1 The concentrations of PTE in the surficial sediment from Makirina bay and their minimum, maximum and mean values

\begin{tabular}{c|ccc}
\multirow{2}{*}{ PTE } & \multicolumn{3}{|c}{$\begin{array}{c}\text { Concentrations } \\
{[\mathrm{ppm}]}\end{array}$} \\
\cline { 2 - 4 } & Min. & Max. & Mean \\
\hline $\mathrm{As}$ & 11 & 15,8 & 13,4 \\
$\mathrm{Cr}$ & 61,6 & 109,5 & 87,4 \\
$\mathrm{Cu}$ & 19,4 & 54,2 & 27,9 \\
$\mathrm{~Pb}$ & 16,8 & 29,6 & 22,3 \\
$\mathrm{Zn}$ & 37 & 52 & 44,2
\end{tabular}

The results obtain in this study were compared with PTE content in the surficial sediment from the central Adriatic (Dolenec et al., 1998) and with PTE content in "virgin" clay, the basic ingredient used for the preparation of the peloid muds in spa centers in northern Italy (Veniale et al., 2004). Contents are shown in Table 2.

Tab.2 PTE content in the surficial sediment from the central Adriatic (Dolenec et al., 1998) and in the "virgin" clay used for the preparation of the peloid muds in spa centers in N Italy (Veniale et al., 2004)

\begin{tabular}{c|cc} 
PTE & $\begin{array}{c}\text { PTE content in surficial } \\
\text { sediment from the } \\
\text { central Adriatic } \\
\text { (Dolenec et al., 1998) } \\
\text { [ppm] }\end{array}$ & $\begin{array}{c}\text { PTE content in } \\
\text { "virgin" clay } \\
\text { used in spa } \\
\text { centers in N } \\
\text { Italy (Veniale } \\
\text { et al., 2004) } \\
\text { [ppm] }\end{array}$ \\
\hline $\mathrm{As}$ & $1-32$ & 3 \\
$\mathrm{Cr}$ & $39-165$ & 115 \\
$\mathrm{Cu}$ & $9,8-32,7$ & 44 \\
$\mathrm{~Pb}$ & $7-14$ & 24 \\
$\mathrm{Zn}$ & $38-95$ & 91
\end{tabular}

Comparing the concentrations obtained in this study with the PTE concentrations in the surficial sediments from the central Adriatic (Dolenec et al., 1998), slightly elevated concentrations of $\mathrm{Cu}$ and $\mathrm{Pb}$ were found.

Elevated $\mathrm{Cu}$ concentrations in Makirina bay are probably because of agricultural activity in the surroundings of the cove (use of Bordeux mixture in wineyards), $\mathrm{Pb}$ accumulations are probably due to traffic around the bay (Vreča et al., 2000).

Comparing the results obtain in this study with PTE content in "virgin" clay used in spa centers in N Italy (Veniale et al., 2004), elevated concentrations of As, Cu and $\mathrm{Pb}$ have been detected. Several PTE in the Makirina bay sediment are strongly related to the catchment geology and as well as the impact of agricultural, 
touristic, domestic and industrial wastes discharged into Pirovac bay both directly and via rivers.

In order to evaluate the assessement of PTE pollution in sediments of Makirina bay $\mathrm{CF}, \mathrm{C}_{\mathrm{deg}}$ and PLI values for sediment were calculated. $\mathrm{CF}, \mathrm{C}_{\mathrm{deg}}$ and PLI values for sediment are shown in Table 3. For the background concentration soil from surroundings of the bay (Vreča, 1998) were used. Background values for several PTE are present in Table 4.

Tab.3 CF, $\mathrm{C}_{\mathrm{deg}}$ and PLI values for sediment from Makirina bay

\begin{tabular}{c|ccc} 
PTE & CF & $\mathrm{C}_{\text {deg }}$ & PLI \\
\hline $\mathrm{As}$ & 1,2 & & \\
$\mathrm{Cr}$ & 0,5 & & \\
$\mathrm{Cu}$ & 0,4 & & \\
$\mathrm{~Pb}$ & 0,6 & & \\
$\mathrm{Zn}$ & 0,6 & & \\
\cline { 2 - 4 } & & 2,2 & 0,6
\end{tabular}

Tab.4 Concentrations in soil from surroundings of the bay (Vreča, 1998)

\begin{tabular}{c|c} 
PTE & $\begin{array}{c}\text { Concentrations in soil from surroundings } \\
\text { of the bay [ppm] } \\
\text { (Vreča, 1998) }\end{array}$ \\
\hline $\mathrm{As}$ & 11 \\
$\mathrm{Cr}$ & 170 \\
$\mathrm{Cu}$ & 68 \\
$\mathrm{~Pb}$ & 36 \\
$\mathrm{Zn}$ & 78
\end{tabular}

The calculated contamination factors show a low to moderate contamination status of the sediment. $\mathrm{C}_{\mathrm{deg}}$ is $<8$, which signifies a low degree of contamination, calculated PLI indicates that there is no PTE pollution in the sediment. However, more geochemical researches on these peloids are necessary, before actual use in therapeutic purposes. Our future geochemical analyses will be focused on various extraction tests to determine the mobility and bioavailability of characteristics PTE in the investigated sediment.

\section{Conclusion}

The range of measured elemental concentrations in analysed surficial sediment were: As (11-15,8 ppm), $\mathrm{Cr}$ (61,6 -109,5 ppm), Cu (19,4-54,2 ppm), Pb (16,8-29,6 $\mathrm{ppm})$ and $\mathrm{Zn}$ (37-52 ppm). Comparing the contents obtained in this study with the PTE concentrations in the surficial sediments from the central Adriatic (Dolenec et al., 1998), slightly elevated concentrations of $\mathrm{Cu}$ and $\mathrm{Pb}$ were found. Comparing the results obtain in this study with PTE content in "virgin" clay used in spa centers in N Italy (Veniale et al., 2004), elevated concentrations of $\mathrm{As}, \mathrm{Cu}$ and $\mathrm{Pb}$ have been found. The calculated environmental indices show a low to moderate contamination status of the sediment. Future geochemical investigation on these sediments are necessary prior actual use in various therapeutic treatment; our further researches will be focused on various extraction tests to determine the mobility and bioavailability of characteristics PTE in the investigated peloids.

\section{Acknowledgements}

The authors thank the financial supports providing from Slovenian research agency (ARRS), contract number: 1000-11-310206.

\section{References}

Carretero MI et al. Mobility of elements in interaction between artficial sweat and peloids used in Spanish spas. Applied clay science 2010; 48: 506-515.

Gomes C, Silva J. Minerals and clay minerals in medical geology. Applied clay science 2007; 36: 4-21.

Hakanson L. Ecological risk index of aquatic pollution control. A sedimentological approach. Water research 1980; 14: 975-1001.

Dolenec $\mathrm{T}$ et al. Major, minor and trace elements in surficial sediments from the open Adriatic sea: A regional geochemical study. Geologia Croatica 1998; 51, 1: 59-73.

Karakaya MC et al. Some properties of thermal muds of some spas in Turkey. Applied clay science 2010; 48: 531-537.

Mascolo $\mathrm{N}$ et al. Characterization of toxic elements in clays for human healing use. Applied clay science 1999; 15: 491-500.

Miko $\mathrm{S}$ et al. Influence of land use in small karst watersheds on the chemical status of peloid sediments on the eastern Adriatic coast. Journal of soils and sediments 2007; 7, 5: 303-312.

Miko S et al. Anthropogenic influence on trace element geochemistry of healing mud (peloid) from Makirina Cove (Croatia). Environmental geology 2008; 55: 517-537.

Mascolo $\mathrm{N}$ et al. In vivo experimental data on the mobility of hazardous chemical elements from clays. Applied clay science 2004; 25: 23-28.

Mihelčić G et al. Physico-chemical characteristics of the peloid mud from Morinje bay (eastern Adriatic coast, Croatia): suitability for use in balneotherapy. Environmental geochemistry and health 2011; 34:191-198.

Novak R. Peloid. Medicinska enciklopedija 1963; 7: 646-650. (in croatian)

Rebelo $\mathrm{M}$ et al. Characterization of Portugese geological materials to be used in medical hydrology. Applied clay science $2011 ; 51: 258-266$.

Summa V, Tateo F. The use of pelitic raw materials in thermal centres: Mineralogy, geochemistry, grain size and leaching tests. Examples from the Lucania area (southern Italy). Applied clay science 1998; 12: 403-417.

Šparica M et al. Peloid uvale Makirina (Pirovački zaljev). Elaborat. Zagreb, Institut za geološka istraživanja, OOUR za geologijo 1989; Br. 28/89: 64 str. (in croatian)

Tateo $\mathrm{F}$ et al. The in-vitro percutaneous migration of 
chemical elements from a thermal mud for healing use. Applied clay science 2009; 44: 83-94.

Tateo F, Summa V. Element mobility in clays for healing use. Applied clay science 2007; 36: 64-76.

Tomlinson DL et al. Problems in the assessment of heavy-metal levels in estuaries and the formation of a pollution index. Helgoländer meeresuntersuchungen 1980; 33: 566-575.

Veniale $\mathrm{F}$ et al. Formulation of muds for pelotherapy: effects of "maturation" by different mineral waters. Applied clay science 2004; 25: 135-148.

Veniale $\mathrm{F}$ et al. Thermal muds: Perspectives of innovations. Applied clay science 2007; 36: 141-147.
Vreča P et al. Evaluation of metal pollution in coastal sediment from Makirina bay in the Central Adriatic. V: Vlahović I (ur.), Biondić R (ur.). 2. hrvatski geološki kongres: Zbornik radova, Cavtat-Dubrovnik, 17.-20.5.2000. Zagreb, Institut za geološka istraživanja; 2000; 475-478.

Vreča P, Dolenec T. Geochemical estimation of copper contamination in the healing mud from Makirina bay, central Adriatic. Environment international 2005; 31: 53-61.

Vreča P. Isotopic and geochemical properties of the recent sediment from the Makirina bay (central Adriatic). M.Sc. thesis, University of Ljubljana, 116 p. (in slovene). 